\title{
Recurrent Malignant Duodenal Neoplasm
}

National Cancer Institute

\section{Source}

National Cancer Institute. Recurrent Malignant Duodenal Neoplasm. NCI Thesaurus.

Code C9263.

The reemergence of a malignant duodenal neoplasm after a period of remission. 